\title{
Epidemiology of Cardiovascular Diseases in Children at the Teaching Hospital of Brazzaville, Congo
}

\author{
Anne Berthe M'pemba Loufoua-Lemay ${ }^{1 *}$, Alphonse Massamba ${ }^{2}$ \\ ${ }^{1}$ Department of Pediatrics, University of Brazzaville Hospital, Brazzaville, Congo \\ ${ }^{2}$ Laboratory of Health, Exercise Physiology and Biomechanics, Superior Institute of Physical Education, University Marien Ngouabi, \\ Brazzaville, Congo \\ Email: *doclemay@yahoo.fr
}

How to cite this paper: M'pemba LoufouaLemay, A.B. and Massamba, A. (2016) Epidemiology of Cardiovascular Diseases in Children at the Teaching Hospital of Brazzaville, Congo. World Journal of Cardiovascular Diseases, 6, 410-424.

http://dx.doi.org/10.4236/wjcd.2016.611045

Received: October 16, 2016

Accepted: November 21, 2016

Published: November 24, 2016

Copyright (๑) 2016 by authors and Scientific Research Publishing Inc. This work is licensed under the Creative Commons Attribution International License (CC BY 4.0).

http://creativecommons.org/licenses/by/4.0/ (c) (i) Open Access

\section{Abstract}

Context: Several studies were conducted throughout the world on heart diseases in children; no data is available in Congolese child. Objective: To evaluate epidemiological profile of Congolese children and teenager carrying cardiovascular diseases. Methods: A descriptive and prospective study was carried out during 4 years in the pediatric department of teaching hospital of Brazzaville, near the children received in consultation of pediatric cardiology. Results: On 41,472 patients admitted in pediatric service, 526 patients were received in consultation for suspicion of heart diseases. Among them, 444 had cardiopathy (incidence of $10.7 \%$ ). It was about a congenital heart disease to 316 (60\%) incidence of 7.6\%; Acquired heart disease to 128 (24.4\%) incidence of $3.1 \%$. Among congenital heart defects observed frequency of patients with ASD was $20.3 \%$, isolated in $10.1 \%$ of cases, and associated with ECD (11.8\%). The VSD was observed in $30.1 \%$ of cases, and the Tetralogy of Fallot in $10.1 \%$ of cases. Among the acquired heart diseases, severe hypo kinetic dilated cardiomyopathy (DCM) was noted in $24.4 \%$ of cases. The rheumatic heart diseases accounted for $41.4 \%$ of cases. It was mitral regurgitation (33.6\%), a mitral stenosis (1.6\%). Pericarditis was objectified at $10.1 \%$ of the patients. The evolution was favorable for $43.3 \%$ of patients. An aggravation of symptoms was observed to $2.7 \%$ of patients. Mortality was $11.9 \%$ and $71.9 \%$ of deaths were observed to not operate carriers of congenital heart disease. $69.9 \%$ of dead patients were carrying a cyanogen heart disease. Left to right shunt represented $21.7 \%$ of the deaths. Conclusion: Heart diseases are real problem of public health for Congolese children.

\section{Keywords}

Congenital Heart Diseases, Acquired Heart Diseases, Children, Brazzaville, 
Sub-Saharan Africa

\section{Introduction}

The heart diseases are various origins. Being able congenital or to be acquired, they touch nearly $1 \%$ of the population with regard to congenital heart diseases and $5 \%$ of the children in others countries as regards the acquired forms [1]. In the tropical countries, they became a major problem of infant and youthful health. Indeed, the cardiac child is a true problem of public health in the countries in the process of development, concerning up to $3 \%$ to $4 \%$ of children with diseases very invalidating and very expensive for their family and the society [1]. In sub-Saharan Africa, the prevalence of heart diseases in youth medium is estimated at approximately 8 per thousand alive births for the congenital heart diseases and at least 1 to 14 per thousand for the rheumatic heart diseases. However, these data remain approximate, the relevant statistical data are usually vague, or do not exist [2]. The situation for sub-Saharan is linked to pernicious environmental conditions like poverty, infections, and poor health habits might exert a deleterious influence [1]. In addition, these cardiac pathologies, during the growth, are increasingly frequent in Congo, with established associated forms. Their prevalence seems to rise of ignorance or refusal of an awakening of certain medical pathologies, like the AIDS and the anginas with streptococcus. With that, the archaism or the absence of medical resources is added, then multiplying the harmful effects of these diseases. Moreover, the prevalence of infectious and parasitic diseases relegates to the second rank the cardiac pathology of the child. It is in this context that heart diseases are described very little in Congo where there exist few publications on cardiovascular pathology of the child. Also, we therefore investigated epidemiologic aspects of cardiac pathologies observed in pediatric department of the teaching hospital of Brazzaville. The objectives specifically assigned to this study are to evaluate the prevalence of heart diseases in Congolese child and teenager and to specify type of heart diseases observed.

\section{Material and Methods}

\subsection{Topics}

The study, descriptive and prospective, was carried out with the teaching hospital of Brazzaville. Patients aged 0 - 15 years received in consultation of pediatric cardiology during the period of 1st June 2009-1st June 2013. The population of Brazzaville, for this period, was $1,373,382$ inhabitants.

\subsection{Methods}

The present work reports on 526 consecutive Congolese young patients admitted or followed up in teaching hospital of Brazzaville. The two-dimensional echocardiography, carried out with an apparatus portable Doppler color (Mr.-Turbo Sonosite, Bo- 
thell, USA) was done for all the patients. The interest data were age, gender, reason for consultation, type of cardiopathy, existence or not of an operational indication, existence or not of a surgical assumption of responsibility and evolution.

\subsection{Statistical Analysis}

They were noted on individual record sheets of collection. We used Epi Info version 6.5.1 (WHO \& CDC) to enter and clean the data, and SPSS (Statistical Package for Social Science) version 16.0 (SPSS Inc, Chicago, IL, USA) to analyze the data. The p-value, less than 0.05 , was regarded as the statistical threshold of significance. The quantitative information was expressed on average accompanied by the standard deviation, the frequencies in the form of percentages. Chi square and Sokal tests were used for comparing categorical and qualitative variables. The comparisons between various groups of heart diseases, like between sex and groups of ages, were carried out using the test of the $\chi^{2}$ of Spearman when indicated.

\section{Results}

\subsection{Distribution of the Patients by Age and Gender (Table 1)}

For the period of study, the number of consultations to the teaching hospital rose with 68,352 patients, including 41,472 patients in pediatry (60.7\%). On the whole, 526 patients were received in pediatric consultations of cardiology $(1.3 \%)$. The present serie comprised $284(54 \%)$ girls and 242 (46\%) boys (sex ratio of 0.85 ). The average age of the patients was 2053 days, either 5 years 7 months (2109 days or 8 months for the girls; 1997 days either or 5 months for the boys) with range: 4 days - 5400 days (15 years). The distribution of the patients according to the age is reported in Table 1.

\subsection{Distribution According to the Reason for Consultation (Table 2)}

The reasons for consultation were summarized with the appearance of a respiratory distress in $26.6 \%$ of cases; respiratory distress associated a murmur heart in $8.2 \%$ of

Table 1. Distribution of patients as function as age and gender.

\begin{tabular}{ccccc}
\hline $\begin{array}{c}\text { Age bracket } \\
\text { (days) }\end{array}$ & $\begin{array}{c}\text { Girls } \\
(\mathrm{n})\end{array}$ & $\begin{array}{c}\text { Boys } \\
(\mathrm{n})\end{array}$ & $\begin{array}{c}\text { Total } \\
(\mathrm{n})\end{array}$ & $\begin{array}{c}\text { Frequency } \\
(\%)\end{array}$ \\
\hline $0-90$ & 51 & 42 & 93 & 17.7 \\
$91-360$ & 74 & 52 & 126 & 24.0 \\
$361-1080$ & 52 & 42 & 94 & 17.9 \\
$1081-2160$ & 38 & 49 & 87 & 16.6 \\
$2161-3240$ & 20 & 22 & 42 & 8.0 \\
$3241-4320$ & 24 & 19 & 43 & 8.2 \\
$4321-5400$ & 25 & 16 & 40 & 7.6 \\
Total & 284 & 242 & 526 & 100 \\
\hline
\end{tabular}


Table 2. Reasons for consultation.

\begin{tabular}{ccc}
\hline Reasons & Number & frequency \% \\
\hline Dyspnea & 140 & 26.6 \\
Dyspnea with heart murmur & 43 & 8.2 \\
Heart murmur & 97 & 18.4 \\
Cyanosis & 27 & 5.1 \\
Chimiotherapy & 27 & 5.1 \\
Follow up of known cardiopathy & 108 & 20.6 \\
Cardiomegaly & 11 & 2.1 \\
Down syndrome & 11 & 2.1 \\
Arrhythmia & 11 & 2.1 \\
Poly malformatif syndrome & 18 & 3.4 \\
Chest pain & 10 & 2.0 \\
Kawasaki disease & 626 & 1.1 \\
Poor growth & 11 & 2.1 \\
Pre operative assessment & 6 & 1.1 \\
Total & 6 & 2.1 \\
\hline
\end{tabular}

cases, perception of murmur heart in $18.4 \%$ of the cases. The assessment of cyanosis and therapeutic pre-assessment for an anti-cancer chemotherapy were the reasons for consultation in $5.1 \%$ of cases. In addition, $20.6 \%$ of patients consulted within the framework of the follow-up of a known cardiopathy from which $18.4 \%$ had already profited from a surgical assumption of responsibility. The discovery of a cardiomegaly on radiographies of thorax, the assessment of Down syndrome, arrhythmias were found respectively in $2.1 \%$ of cases. The assessment of polymalformative syndrome justified the consultation in $3.1 \%$ of cases. The other reasons for consultation were pains of left hemi thorax, suspicion of syndrome of Kawasaki, presence of hypotrophy, or preoperative assessment at homozygous sickle cell diseases (Table 2).

\subsection{Distribution According to the Existence or Not of Cardiac Diseases}

On the whole, $82(15.6 \%)$ patients presented a normal aspect of the heart. However, 444 patients had cardiopathy with an incidence of $10.7 \%$. It was about congenital heart diseases at $316(60 \%)$ patients either an incidence of $7.6 \%$ and acquired heart diseases at $128(24.4 \%)$ patients with an incidence of $3.1 \%$.

\subsection{Distribution of the Patients with Congenital Heart Diseases According to Age and Gender (Table 3)}

The population of the patients with congenital heart diseases comprised 173 girls and 
Table 3. Distribution according to age and gender for patients with congenital heart diseases.

\begin{tabular}{ccccc}
\hline $\begin{array}{c}\text { Age bracket } \\
(\text { days })\end{array}$ & $\begin{array}{c}\text { Girls } \\
(\mathrm{n})\end{array}$ & $\begin{array}{c}\text { Boys } \\
(\mathrm{n})\end{array}$ & $\begin{array}{c}\text { Total } \\
(\mathrm{n})\end{array}$ & $\begin{array}{c}\text { Frequency } \\
(\%)\end{array}$ \\
\hline $0-90$ & 38 & 31 & 69 & 21.9 \\
$91-360$ & 64 & 36 & 100 & 31.7 \\
$361-1080$ & 37 & 33 & 70 & 22.2 \\
$1081-2160$ & 18 & 26 & 44 & 14.0 \\
$2161-3240$ & 6 & 6 & 12 & 3.8 \\
$3241-4320$ & 5 & 6 & 11 & 3.5 \\
$4321-5400$ & 5 & 5 & 10 & 2.8 \\
Total & 173 & 143 & 316 & 100 \\
\hline
\end{tabular}

143 boys (sex-ratio to 0.83 ). The average age bordered 2087 days is 7 months (range: 4 15 years). The old patients aged to 0 - 3 years represented $75.9 \%$ of manpower; moreover, $53.6 \%$ of patients were less than one year old. The patients of more than 12 years represented $7.3 \%$ of manpower.

\subsection{Distribution According to the Type of Congenital Heart Diseases Observed (Table 4 and Table 5)}

The atrial septal defect (ASD) was objectified in $20.3 \%$ of the cases (Figure 1). It was insulated in $10.5 \%$ from cases and was associated aendocardial cushion defect (ECD) in $11.8 \%$ of cases (Figure 2). A ventricular septal defect (VSD) was observed in $30.1 \%$ of cases, insulated in $24.4 \%$ from cases (Figure 3). The Tetralogy of Fallot was found among 32 patients ( $10.1 \%$ of cases).

\subsection{Congenital Heart Diseases and Chromosomal Anomalies}

Among the 27 patients with Down syndrome 19 girls and 8 boys were found (sex-ratio to 0.42 ). Ten eights of these patients were carrying endocardial cushion defect (ECD), that is to say $66.7 \%$ of patients with Down syndrome; they were 14 girls and 4 boys versus 5 carriers of ECD among patients without Down syndrome. Association the ASD ostium secondum and ECD was observed only among 8 patients with Down syndrome (44.4\%). Other cardiac malformations were observed on this ground: the ASD ostium secondum insulated among two patients, the ASD ostium secondum and VSD perished membranous in two cases, VSD perished membranous and PDA at a patient, VSD insulated among three patients. A patient presented a heart without anomaly, (3.7 \% from Down syndrome).

A syndrome of Noonan was observed among three carrying patients presented respectively pulmonary valvular stenosis, VSD of type III with PDA and ASD ostium secondum. In addition, two patients of same fratry were carrying a severe hypokinetic dilated cardiomyopathy of origin family (form related to X). 


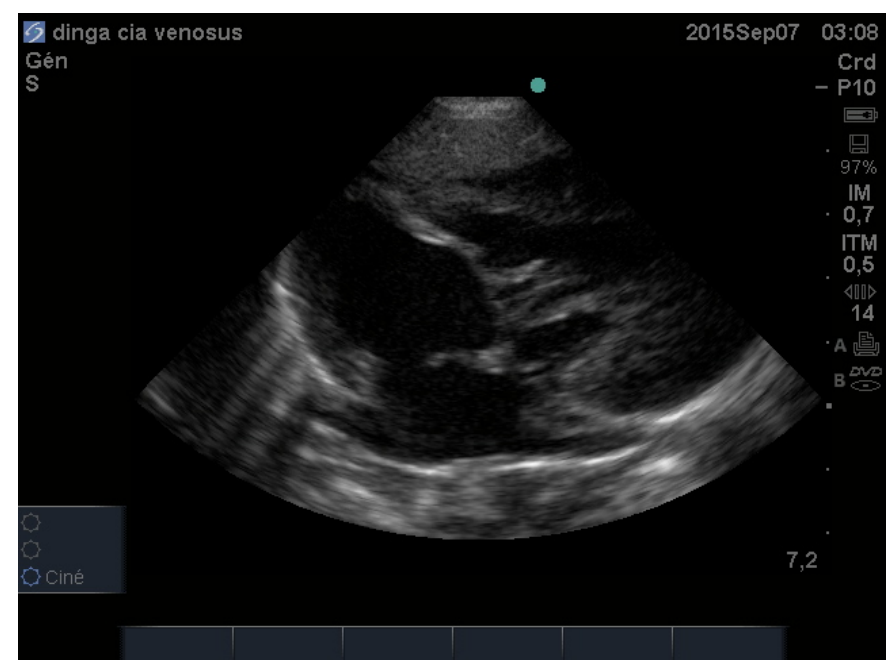

Figure 1. Atrio septal defect.

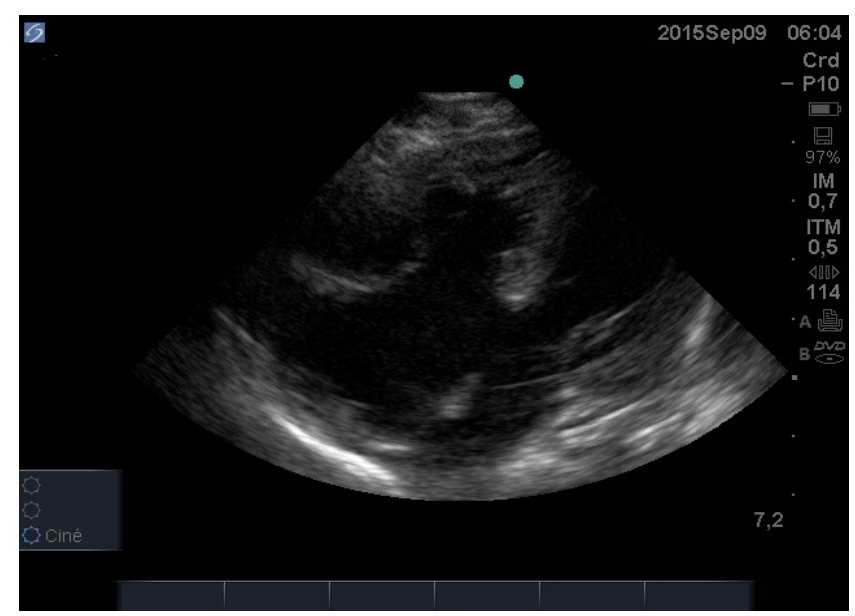

Figure 2. Endocardial cushion defect with atrio septal defect ostium primum.

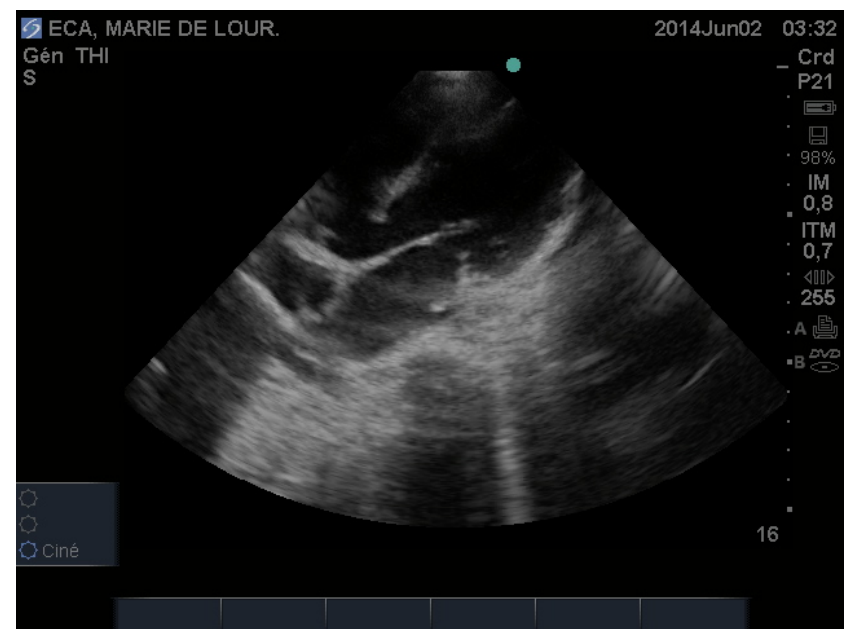

Figure 3. Ventricular septal defect. 
Table 4. Distribution of patients as function as type of congenital heart diseases.

\begin{tabular}{|c|c|c|c|c|}
\hline Type of heart defects & $\begin{array}{c}\text { Girls } \\
\text { (n) }\end{array}$ & $\begin{array}{c}\text { Boys } \\
\text { (n) }\end{array}$ & $\begin{array}{l}\text { Total } \\
\text { (n) }\end{array}$ & $\begin{array}{c}\text { Frequency } \\
(\%)\end{array}$ \\
\hline ASD & 37 & 27 & 64 & 20.3 \\
\hline ASD insulated & 21 & 12 & 33 & 10.5 \\
\hline Associated to: VSD & 6 & 8 & 14 & \\
\hline ECD & 6 & 2 & 8 & \\
\hline PDA & 1 & 2 & 3 & \\
\hline DORV & 0 & 1 & 1 & \\
\hline PS & 3 & 1 & 4 & \\
\hline PAIVS & 1 & 1 & 2 & \\
\hline VSD & 46 & 49 & 95 & 30.1 \\
\hline VSD insulated & 40 & 37 & 77 & 24.4 \\
\hline Associated to: TGA & 2 & 2 & 4 & \\
\hline PS & 2 & 4 & 6 & \\
\hline PDA & 1 & 5 & 6 & \\
\hline $\mathrm{AR}$ & 0 & 1 & 1 & \\
\hline Dextrocardy & 1 & 0 & 1 & \\
\hline ECD & 16 & 8 & 24 & 7.6 \\
\hline insulated & 9 & 1 & 10 & 2.2 \\
\hline Associated to: ASD os & 6 & 2 & 8 & \\
\hline PDA & 1 & 1 & 2 & \\
\hline DORV & 0 & 3 & 3 & \\
\hline aorto ventricular chanel & 1 & 0 & 1 & \\
\hline Pulmonary atresia & 0 & 1 & 1 & \\
\hline PDA & 21 & 16 & 37 & 11.7 \\
\hline Associated to: ECD & 1 & 1 & 2 & \\
\hline VSD & 2 & 5 & 7 & \\
\hline Tetralogy of Fallot & 0 & 1 & 1 & \\
\hline ASD & 1 & 2 & 3 & \\
\hline DORV & 3 & 4 & 7 & 2.2 \\
\hline Associated to: PS & 2 & 0 & 2 & \\
\hline PDA & 1 & 0 & 1 & \\
\hline SV & 1 & 1 & 2 & 0.6 \\
\hline Associated to: PTA (persistent truncus arteriosus) & 0 & 1 & 1 & \\
\hline Hypoplatic left heart & 2 & 1 & 3 & 0.6 \\
\hline Associated to: GAT & 1 & 0 & 1 & \\
\hline GAT & 1 & 2 & 3 & 0.9 \\
\hline Associated to: VSD & 0 & 1 & 1 & \\
\hline Hypoplastic left heart & 0 & 1 & 1 & \\
\hline
\end{tabular}

ASD: atrio septal defect; ECD: endocardial cushion defect; VSD: ventricular septal defect; GAT: great artery transposition; PS: pulmonary stenosis; AR: aortic regurgitation; DORV: double-outlet right ventricle; PAIVS: pulmonary atresia with intact ventricular septum; PAVSD: pulmonary atresia with ventricular septal defect; PDA: patent ductus arteriosus. 
Table 5. Other types of congenital heart diseases observed.

\begin{tabular}{|c|c|c|c|c|}
\hline & $\begin{array}{l}\text { Girls } \\
\text { (n) }\end{array}$ & $\begin{array}{l}\text { Boys } \\
\text { (n) }\end{array}$ & $\begin{array}{l}\text { Total } \\
\text { (n) }\end{array}$ & $\begin{array}{c}\text { Frequency } \\
(\%)\end{array}$ \\
\hline Tetralogy of Fallot & 12 & 20 & 32 & 10.1 \\
\hline Associated to: PDA & 1 & 0 & 1 & \\
\hline PS & 21 & 10 & 3 & 29.8 \\
\hline Insulated & 15 & 7 & 22 & 7.0 \\
\hline Associated to: DORV & 2 & 0 & 2 & 0.6 \\
\hline VSD & 2 & 4 & 6 & \\
\hline ASD & 3 & 1 & 4 & \\
\hline PAVSD & 4 & 7 & 11 & 3.5 \\
\hline PAIVS & 0 & 1 & 1 & 0.3 \\
\hline Ebstein's anomaly & 2 & 0 & 2 & 0.6 \\
\hline pulmonary ectasia & 0 & 1 & 1 & 0.3 \\
\hline cor Triatriatum & 0 & 1 & 1 & 0.3 \\
\hline PTA & 1 & 4 & 5 & 1.6 \\
\hline Associated to: SV & 0 & 1 & 1 & 0.3 \\
\hline long QT syndrome & 0 & 1 & 1 & 0.3 \\
\hline $\begin{array}{l}\text { Rabdomyoma of tuberous sclerosis } \\
\text { of Bourneville }\end{array}$ & 1 & 0 & 1 & 0.3 \\
\hline
\end{tabular}

\subsection{Distribution of the Patients with Acquired Heart Diseases According to Age and Gender (Table 6)}

They were found among 68 girls and 60 boys (sex-ratio to 0.88 ). The average age of these patients was 2012 days ( 5 years 5 months). Among them, $82.8 \%$ of the patients were old of more than 3 years.

\subsection{Distribution According to Type of Acquired Heart Diseases (Table 7)}

The severe hypokinetic dilated cardiomyopathy was noted in $24.2 \%$ of cases and they were observed in all the age brackets. The rheumatic heart diseases represented $41.4 \%$ of cases. Their incidence in the population of child received at the teaching hospital of Brazzaville for the period of study was $1.1 \%$. These rheumatic heart diseases were observed as of 3 years. The lesions observed were mitral regurgitation (MR) in $3.6 \%$ of cases (43 patients), associated to aortic regurgitation among $2.3 \%$ of patients ( 3 cases) and mitral stenosis (MS) in $1.6 \%$ of cases (Figure 4). A pericarditis was objectified at $10.1 \%$ of patients.

A suffering patient of an infection with AIDS was carrying a myocarditis. 
Table 6. Distribution according to age and gender of patients with acquired heart diseases.

\begin{tabular}{ccccc}
\hline $\begin{array}{c}\text { Age bracket } \\
(\text { days })\end{array}$ & $\begin{array}{c}\text { Girls } \\
(\mathrm{n})\end{array}$ & $\begin{array}{c}\text { Boys } \\
(\mathrm{n})\end{array}$ & $\begin{array}{c}\text { Total } \\
(\mathrm{n})\end{array}$ & $\begin{array}{c}\text { Frequency } \\
(\%)\end{array}$ \\
\hline $0-90$ & 3 & 3 & 6 & 4.7 \\
$91-360$ & 5 & 3 & 8 & 6.2 \\
$361-1080$ & 4 & 4 & 8 & 6.2 \\
$1081-2160$ & 15 & 16 & 31 & 24.2 \\
$2161-3240$ & 8 & 14 & 22 & 17.2 \\
$3241-4320$ & 16 & 10 & 26 & 20.3 \\
$4320-5400$ & 17 & 10 & 27 & 21.1 \\
Total & 68 & 60 & 128 & 100 \\
\hline
\end{tabular}

Table 7. Distribution as function as type of acquired heart diseases.

\begin{tabular}{lcc}
\hline \multicolumn{1}{c}{ Type of heart diseases } & Total & Frequency \\
\hline Myocarditis & 3 & 2.3 \\
Myopericarditis & 4 & 3.1 \\
Péricarditis & 13 & 10.1 \\
Bacterian endomyopericarditis & 1 & 0.8 \\
Rheumatismal pancarditis & 2 & 1.6 \\
Rheumatismal valvulopathies: & & \\
$\quad$ MR & 40 & 31.2 \\
$\quad$ Mitral disease & 1 & 1.6 \\
MR+AR & 3 & 2.3 \\
Dilated cardiomyopathies: & & 24.2 \\
\multicolumn{1}{c}{ Hypokinétique sévère } & 31 & 8.6 \\
Cardiomyopathie whith SSD & 11 & 0.8 \\
Fibrosis endomyocarditis & 1 & 0.8 \\
Hypertrophic cardiomyopathies & 2 & 1.6 \\
Primitive pulmonary hypertension & & \\
\hline
\end{tabular}

\subsection{Distribution of the Patients According to the Mode of Assumption of Responsibility}

On the whole, 240 patients (45.7\%) had an operational indication. Among them 103 were operated ( $42.9 \%$ of cases) thanks to French ONG (Chain of the Hope, cardiac Mécénat surgery). A total of 6 pericardial drainages had been carried out in local surgical medium. Moreover, 137 other patients were in waiting of surgical assumption of responsibility. However, 19 patients, because of existence of Down syndrome were not 


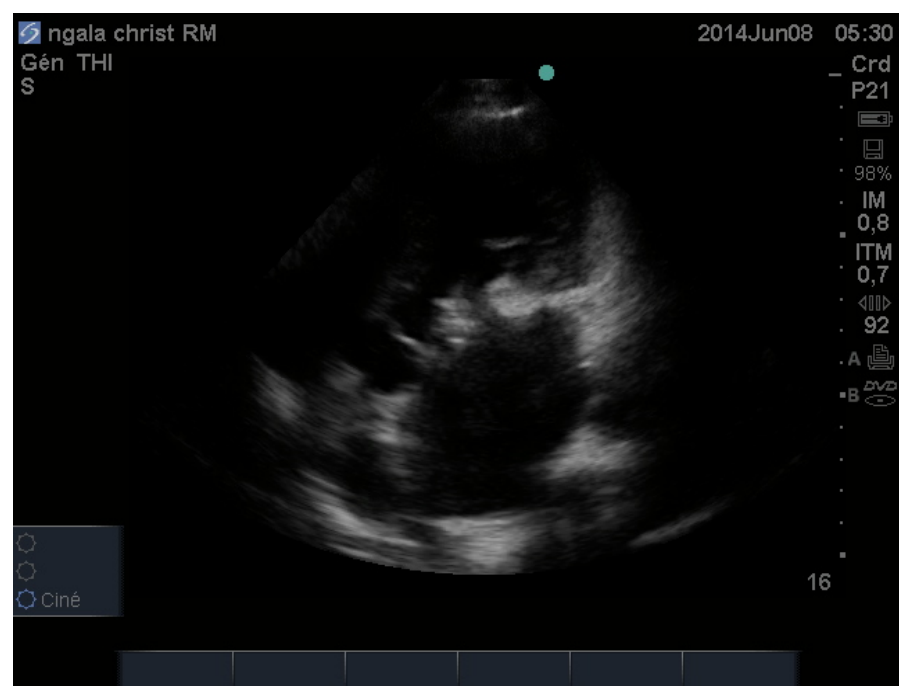

Figure 4. Rheumatismal mitral stenosis.

eligible for an assumption of responsibility by the ONG, like 7 patients carrying a systemic pulmonary hypertension.

\subsection{Evolution}

The evolution could be specified only for 261 patients (49.7\% of cases). The evolution was favorable among 113 patients (43.3\%), stable at 69 patients (26.4\%). An aggravation of symptoms was noted among 7 patients, (2.7\% of cases). Mortality frequency was $11.9 \%$ is 31 patients: 19 girls and 12 boys. In addition, $71.9 \%$ of the deaths were observed among not operated patients carrying congenital heart diseases. Moreover, $69.6 \%$ of patients deceased $(n=16)$ were carrying a cyanotic congenital heart defects: PAVSD, 4 cases; PAISV, 1 case; Tetralogy of Fallot, 5 cases; TGA, 3 cases; Hypoplastic left heart, 2 cases; DOVR, 1 case. The heart defect with left to right shunt accounted for $21.7 \%$ of the deaths ( 5 cases); $8.69 \%$ of these deaths were observed among patients carrying a tight pulmonary stenosis. Last nine deaths were noted among patients carrying an acquired heart disease: 4 patients carrying a rheumatic valvulopathy, 3 of péricarditis, 2 of a severe hypokinetic dilated myocardiopathy. Moreover, two patients had died respectively: of oil ingestion and a neurological malaria, their cardiopathy not being the cause of their death. The average age of the patients deceased was 758 days is 2 years 10 months for congenital heart diseases (range: 4320 - 3176 days).

\section{Discussion}

Our study, in spite of skews related to its hospital character, makes it possible to have an idea on the frequency and the types of heart diseases observed in Congolese pediatric medium. The numbers of heart diseases recruited in 4 years is more significant than those noted in studies former carried out to Congo in pediatric medium [3] [4], because of the limitation of the means of investigation, particularly of the scarcity of the apparatuses of Doppler echography in the near total of the centers of health as observed 
in the majority of the countries of sub-Saharan Africa and in Madagascar [5] [6]. Indeed, the presence of an echograph portable color Doppler and medical agents trained in the pediatric department of teaching hospital of Brazzaville contributed to the improvement of the tracking of the heart diseases thus, shortening the deadlines diagnoses and of assumption of responsibility. As observed by Ba et al. [7], Deloche et al. [8], Bazolo et al. [9] the congenital heart diseases were the heart diseases most observed in our study. Compared with the former studies carried out in the same department [3], the number of congenital diseases observed in four years is higher significant than that noted in 12 years ( 315 vs 73 ). The age with the diagnosis was earlier. Indeed, the least old patient had 4 days vs 9 months, and the old patients to 3 years constituted $75.86 \%$ of manpower vs $16.5 \%$ for those from 0 to 3 years [3].

Contrary to the observations of Kinda et al. [6], Gnansia et al. [10] in our series, as that of Baragou et al. [11] and Bazolo et al. [9], the frequency of girls was higher than the boys, without significant difference: $54.2 \%$ for the girls against $45.8 \%$ for the boys ( $\mathrm{p}$ $>0.05$ ). On the other hand, Damorou et al. [12] observe an equality of distribution according to gender.

With regard to the reasons for consultation, the respiratory embarrassment and the heart murmur were the principal reasons for consultation in our series, followed cyanosis. Kinda et al. [6], Baragou et al. [11] also find presence of a heart murmur in the principal reasons for consultation. In our series as in those of Damorou et al. [12], Bazolo et al. [9], respiratory embarrassment was the first reason for consultation. However, the heart murmur was observed in quasi similar proportions.

In Europe particularly in France, the antenatal diagnosis of congenital heart diseases has more than 25 years [13]. This has as a corollary a antenatal diagnosis of congenital heart diseases which reaches a little more than $50 \%$. This detection is definitely higher for the ventricular defects plain as the hypoplastic left heart for which the rate of antenatal tracking is higher than $90 \%$ [14]. For any of our patients, the diagnosis of congenital heart diseases was not made before the birth. Therefore, it is necessary to underline with Sidi [15] early detection of heart diseases which can be effective only by one new policy of public health, organized around medical agents trained with the use an echographic Doppler portable color apparatuses.

As observed before [3], the heart defects with left to right shunt proved to be higher (69.8\% of cases). The VSD were malformation the most observed (30.1\%), insulated or associated to other cardiac malformations, followed ASD (20.3\%) and PDA (11.7\%). This strong proportion of congenital heart diseases with left to right shunt with prevalence of the VSD is also brought back by Deloche et al. [8], Kinda et al. [6], Bazolo et al. [9], with a less incidence of right to left shunt marked by a broad frequency of Tetralogy of Fallot as observed in our study. Indeed, Tetralogy of Fallot remained the most frequent cyanotic cardiopathy ( $10.1 \%$ of cases), though occupying the fourth position by order of frequency of the heart diseases observed. It was followed pulmonary stenosis $(9.8 \%)$ and endocardial cushion defect (7.6\%). Affangla et al. [16] in their series also note this high preponderance of Tetralogie of Fallot, but on the whole of congenital 
heart diseases. In a former study [3], this prevalence of Tetralogie of Fallot was also observed, probably related to the diagnoses criteria. Indeed, the presence of a cyanosis more easily draws the attention of an agent of health to the possibility of a cardiac defect and the need for a specialized consultation. Baragou et al. [11] out of 292 cases finds it in third position after the VSD and the PDA.

In addition, the girls with ECD were higher than boys (16 cases against 8 cases), as described by Gnansia et al. [10] and like observed before [3]. Concerning ECD, 79.2\% of the patients with Down syndrome were as described in the literature [10]; however, associations between ASD ostium secondum and ECD in our series were observed only among at Down syndrome patients.

As for acquired heart diseases, they were observed than the congenital ones as other authors [17] bring it back. For Bode et al. [17], in their study relating to 580 patients having cardiac examination with echocardiography, these authors noted $67.2 \%$ of congenital heart diseases and $28.8 \%$ of acquired heart diseases, frequencies comparable with those observed in our series (respectively $60 \%$ and $24.4 \%$ ).

Being the rheumatic valvulopathies, they were the first motivation of cardiopathy acquired in our series (41.4\% of cases), as in the studies of Affagla et al. [16], Vahanian et al. [18], Deloche et al. [8], Bode et al. [17]. Their incidence represented the third $(1.1 \%)$ acquired heart diseases observed in paediatric medium at teaching hospital of Brazzaville. This incidence corroborates that reported by Moyen et al. [4] in the schoolboys of the suburban districts of Brazzaville (1.4\%). The rheumatic heart diseases are the acquired heart diseases most frequent in the child in sub-Saharan Africa [19], whereas they are rare in Europe because of improvement of socio-economic conditions of populations and the correct assumption of responsibility of the anginas. Frequent and serious in the countries in the process of development, they at the origin of 500,000 died per year [19]. In our series, their appearances were early; the youngest patients were on average 3 years old 6 months at 4 years (6.9\% of the rheumatic valvular heart diseases). Our data are compared to those of Affaga et al. [16], Moyen et al. [4], Yayehd et al. [20]. We noted a female prevalence (no significant difference: 27 girls against 23 boys). The valvular diseases with type of mitral regurgitation, as for them, were observed. Kimbally-Kaky et al. [21] in Congo, in a former study, also observed this prevalence of the mitral regurgitation in $87.5 \%$ of cases, frequency close to that observed by Kramoh et al. [22] in Ivory Coast (87.3\% of cases). This mitral regurgitation was isolated at $86.9 \%$ from patients with associated to mitral stenosis (1.6\% of reports) or aortic regurgitation (2.3\% of cases).

The severe hypokinetic dilated cardiomyopathy occupy the second rank of the acquired heart diseases in our series (24.2\%). Bode et al. [17] in Nigeria also observed them in second position after rheumatic heart diseases. However, in same country Wilson et al. [23] observe a retreat of rheumatic heart diseases, dilated cardiomyopathy becoming the most observed heart diseases. These observations snags lays of a real regression of rheumatic valvulars lesions which would be then related to a notable epidemiologic change in Nigeria compared to the former studies where they occupied the 
first place among acquired heart diseases. However, Sani et al. [24] in the western north of Nigeria note that rheumatic heart diseases occupy the first place among the acquired heart diseases, cardiomyopathy occupying the second position.

The hypokinetic dilated cardiomyopathy, in our series, were observed in all the age brackets. Noted as of the neonatal period, these very early cardiomyopathy could be secondary with neonatal myocarditis, myocardial ischemia post anoxic or endomyocardic fibrosis [25]. The hypokinetic dilated cardiomyopathy was followed bacterial and viral pericarditis $(10.1 \%)$ and cardiomyopathy with sickle cell disease $(8.6 \%)$. The secondary ventricular dysfunction with anemia in the child with sickle cell disease appear in our series as of the second year by the means of a cardiomegaly of adaptation with hyperkinesis and the signs of cardiac failure related to anemia. Kane et al. [26] in Senegal confirm the frequency of patients of sickle cell disease of the dilation of the cardiac cavities associated the hyper kinesis of the left ventricle.

One of our patients suffering from AIDS presented a myocarditis. Indeed, the cardiac diseases became a significant factor of AIDS; approximately $2.1 \%$ to $7.5 \%$ of the people reached of AIDS suffer from a significant cardiac failure [27].

Our data report that half of the patients having an operational indication could profit from surgical assumption of responsibility primarily in France thanks to no governmental french organizations (ONG) (Chain of the Hope, Cardiac Mecenat Surgery). Indeed, as observed by other authors [2] [5] [6] [8] [11] [16] [20], the surgical assumption of responsibility is a real problem for the countries with limited resources. Consequently, the surgical assumption of responsibility of the heart diseases is often ensured by ONG after transfers medical in Europe. Although the technical plate of the teaching hospital of Brazzaville was reinforced by the installation of artificial heart by the Chain of the Hope, thus allowing the interventions opened heart, the qualified staff shortage does not allow his use by a local team (three of the patients of our series were operated in Brazzaville by a team of the Chain of the Hope).

The evolution could be specified only for about half of the patients. Indeed, the absence of medical unit dedicated to the pediatric cardiology explains variability of patients in the four pediatrics services which account the teaching hospital of Brazzaville.

Lastly, 23 deaths were noted among patients with congenital heart diseases, primarily at not operated. The cyanotic congenital heart defects were lethal: 16 reports among 23, i.e. $69.6 \%$ of the deaths. This higher lethality was also observed by Rasamoelisoa et al. [5], Bazolo et al. [9]. It was prevalent in our series among patients having an operational indication, but not taken charges some surgically. This snag lays of formation of specialists and installation of structures dedicated to the assumption of responsibility of these heart diseases either starting from the interventional catheterizations [28] or by the surgery in open heart according to indications.

\section{Conclusion}

Although occulted in sub-Saharan Africa, heart diseases of the child are a real problem of public health because of their importance and the difficulties of assumption of re- 
sponsibility related on poverty of technical plates and lack of specialists in cardiovascular surgery for the forms requiring a surgical assumption of responsibility. And the equipment staff training out of apparatus of echography Doppler color would contribute to the diagnosis and the early assumption of responsibility of its patients. It will be convenient to consider the creation of a center of surgical assumption of responsibility of these heart diseases, being able to be integrated in an existing national structure or into vocation under regional. As for the rheumatic heart diseases, first cause of acquired heart diseases, their prevention by education and treatment correct of the streptococcus anginas as well as the improvement of the conditions of hygiene could reduce the frequency like that of it was observed in the developed countries or these pathologies became rare.

\section{References}

[1] Sidi, D.(1999) Prise en charge des cardiopathies chez l'enfant dans les pays en voie de développement. Archives de Pédiatrie, 6, 465-467. https://doi.org/10.1016/s0929-693x(99)80449-7

[2] Sidi, D. (2000) Cardiologie pédiatrique dans les pays en développement. Ann Nest, 58, 31-41.

[3] M'pemba Loufoua Lemay, A.B., Johnson, E.A. and N'zingoula, S. (2005) Les cardiopathies congénitales observées dans le service de pédiatrie grands enfants de CHU de Brazzaville. Médecine d Afrique Noire, 52, 173-177.

[4] Moyen, G., Okoko, A.R., Mbika Cardorelle, A., Obengui, Gombet, T., Ekoundzola, J., Mabiala, R., Ibala, R. and Samba, C. (1999) Rhumatisme Articulaire aigu et cardiopathie rhumatismales de l'enfant à Brazzaville. Médecine d'Afrique Noire, 46, 259-263.

[5] Rasamoelisoa, J., Raobijaona, H., Tovone, X.G., Rajaonarivelo, A. and Rakotoarimanana, D.R. (2000) Prise en charge des cardiopathies infantiles à Madagascar. Quelles perspectives pour demain? Archives de Pédiatrie, 7, 573.

https://doi.org/10.1016/S0929-693X(00)89022-3

[6] Kinda, G., Millogo, G.R., Koueta, F., Dao, L., Talbousouma, S., Cisse, C., Djiguimde,A., Yé, D. and Sorgho, C.L. (2015) Cardiopathies congénitales: aspects épidémiologiques et écho cardiographiques à propos de 109 cas au Centre hospitalier universitaire pédiatrique Charles de Gaule de Ouagadougou, Burkina Faso. Pan African Medical Journal, 81, 5624.

[7] Ba, M.L. and Kane, F.B. (2000) Etude préliminaire des cardiopathies chez l'enfant mauritanien. Médecine d' Afrique Noire, 47, 492-493.

[8] Deloche, A., Babatasi, G., Baron, O., Roux, D., Chauvaud, S., Sidi, D. and Vouhé, P. (2011) La chirurgie cardiaque pédiatrique dans les pays en voie de développement. Vingt ans d'expérience de la Chaîne de l'Espoir. Bulletin de 1 Académie Nationale de Médecine, 195, 305-308.

[9] Bazoloba Ngouala, G.A., Affangla, D.A., Leye, M. and Kane, A. (2015) The Prevalence of Symptomatic Infantile Heart Disease at Louga Regional Hospital, Senegal. Cardio Vascular Journal of Africa, 26, 55-59.

[10] Gnansia, E.R., Francannet, C., Bozio, A. and Bouvagnet, P. (2004) Epidémiologie, étiologie et génétique des cardiopathies congénitales. EMC-Cardiologie Angéiologie, 1, 140-160. https://doi.org/10.1016/j.emcaa.2004.02.002

[11] Baragou, S., Afassinou, M., Atta, B., Pio, M.,Goeh-akouele, E. and Damorou, F. (2013) Aspects épidémiologique et diagnostiques des cardiopathies congénitales dans une unité 
d'échocardiographie pédiatrique a Lomé(Togo): Etude prospective de Juillet 2010 à Décembre 2012. Journal de la Recherche Scientifique de P Universite de Lome, 15, 343-352.

[12] Damorou, F., Matey, K., Douti, N., Djaato, A., Sossou, B. and Kessie, K. (2010) Les cardiopathies congénitales au Togo, aspects épidémiologiques, cliniques, diagnostiques et thérapeutiques: A propos de 141 cas colligés à la Terre des Hommes (TDH). Journal de la Recherche Scientifique de I Universite de Lome, 12, 47-52. https://doi.org/10.4314/jrsul.v12i1.57102

[13] Bonnet, D. (2009) Le diagnostic prénatal des cardiopathies congénitales. Archives de Pediatrie, 16, 625-627. https://doi.org/10.1016/S0929-693X(09)74091-6

[14] Lelong, N., Thieulin, AC., Vodouar, V., Goffinet, F. and Khoshnood, B. (2012) Surveillance épidémiologique et diagnostic prénatal des malformations congénitales en population parisienne: évolution sur 27 ans, (1981-2007). Archives de Pediatrie, 19, 1030-1038. https://doi.org/10.1016/j.arcped.2012.06.021

[15] Sidi, D. (2011) Les cardiopathies congénitales dans les pays pauvres et la prévention de leurs complications. Bulletin de I Académie Nationale de Médecine, 195, 309-314.

[16] Affangla, DA., Bazolo, GA., Leye, M., Fatou, AW. and Kane, A. (2014) Prise en charge des cardiopathies infantiles a propos de 43 enfants diagnostiqués à Thiès (Sénégal) et opérés. Médecine d Afrique Noire, 61, 202-212.

[17] Bode-Thomas, F., Ige, O.O. and Yilgwan, C. (2013) Childhood Acquired Heart Diseases in Jos, Northcentral Nigeria. Nigerian Medical Journal, 54, 51-58. https://doi.org/10.4103/0300-1652.108897

[18] Vahanian, A., Garbarz, E. and Iung, B. (2011) Les cardiopathies acquises de l'enfant dans les pays en voie de dévellopement. Bulletin de I Académie Nationale de Médecine, 195, 315-326.

[19] Monsuez, J.J. (2011) Valvulopathies Rhumatismales. AMC Pratique, 200, 28-31.

[20] Yayehd, K., Kouleka, D., Tchamdja, T., Tcherou, T., Pessinaba, S. and Damorou, F. (2012) Valvulopathies rhumatismales à Lomé: Aspects épidémiologiques et prise en charge. Journal de la Recherche Scientifique de I Universite de Lome, 14, 51-58.

[21] Kimbally-Kaky, G., Makoumbou, P. and N'zingoula, S. (2002) Le rhumatisme articulaire aigu chez l'enfant en République du Congo. Dakar Médical, 47, 57-59.

[22] Kamoh, K.E., Ngoran, Y.N.K., Aké-Traboulsi, E., Konin, K.C., Boka, B.C., Koffi, D.B.J., Sow, T.M., Mandah, Y.C. and Kakou-Guikahue, M. (2013) Cardite rhumatismale en Côted'Ivoire: Evolution de la prévalence hospitalière durant la décennie 2000-2009. EMC-Cardiologie Angéiologie, 62, 34-37. https://doi.org/10.1016/j.ancard.2012.03.001

[23] Wilson, S.E., Chinyere, U.C. and Queennette, D. (2014) Childhood Acquired Heart Disease in Nigeria: An Echocardiographic Study from Three Centres. African Health Sciences, 14, 609-616. https://doi.org/10.4314/ahs.v14i3.16

[24] Sani, U.M., Ahmed, H. and Jiya, N.M. (2015) Pattern of Acquired Heart Diseases among Children Seen in Sokoto, North-Western Nigeria. Nigerian Journal of Clinical Practice, 18, 718-725. https://doi.org/10.4103/1119-3077.163284

[25] Giroux, J.D. and Finel, E. (1998) Pratique de l'échocardiographie doppler: Hémodynamique et cardiopathies congénitales en néonatologie et réanimation néonatale. Springer, Paris, $160 \mathrm{p}$.

[26] Kane, A., Mbengue-Dièye, A., Dièye, O., Sylla, A., Sall, G., Diouf, S.M. and Kuakuvi, N. (2001) Aspects échographiques au cours de la drépanocytose en milieu pédiatrique. Archives de Pediatrie, 8, 707-712. https://doi.org/10.1016/S0929-693X(00)00302-X

[27] Heffernan, M. and Abramson, B. (2000) Le VIH et le cœur. Cardiol Conf Scien, 5.

[28] Rey, C. (2004) Traitement des cardiopathies congénitales par cathétérisme interventionnel. Archives de Pediatrie, 11, 639-641. https://doi.org/10.1016/j.arcped.2004.03.007 
Submit or recommend next manuscript to SCIRP and we will provide best service for you:

Accepting pre-submission inquiries through Email, Facebook, LinkedIn, Twitter, etc. A wide selection of journals (inclusive of 9 subjects, more than 200 journals)

Providing 24-hour high-quality service

User-friendly online submission system

Fair and swift peer-review system

Efficient typesetting and proofreading procedure

Display of the result of downloads and visits, as well as the number of cited articles

Maximum dissemination of your research work

Submit your manuscript at: http://papersubmission.scirp.org/

Or contactwjcd@scirp.org 